\title{
Miranda
}

Revue pluridisciplinaire du monde anglophone /

Multidisciplinary peer-reviewed journal on the English-

speaking world

$20 \mid 2020$

Staging American Nights

\section{Little Joe Gould Arrives in Truro}

\section{Rachel Brown}

\section{OpenEdition}

\section{Journals}

Electronic version

URL: http://journals.openedition.org/miranda/26519

DOI: 10.4000/miranda.26519

ISSN: $2108-6559$

\section{Publisher}

Université Toulouse - Jean Jaurès

\section{Electronic reference}

Rachel Brown, "Little Joe Gould Arrives in Truro", Miranda [Online], 20 | 2020, Online since 20 April 2020, connection on 16 February 2021. URL: http://journals.openedition.org/miranda/26519; DOI: https://doi.org/10.4000/miranda.26519

This text was automatically generated on 16 February 2021.

\section{$\Theta \Theta \Theta \Theta$}

Miranda is licensed under a Creative Commons Attribution-NonCommercial-NoDerivatives 4.0 International License. 


\section{Little Joe Gould Arrives in Truro}

\section{Rachel Brown}

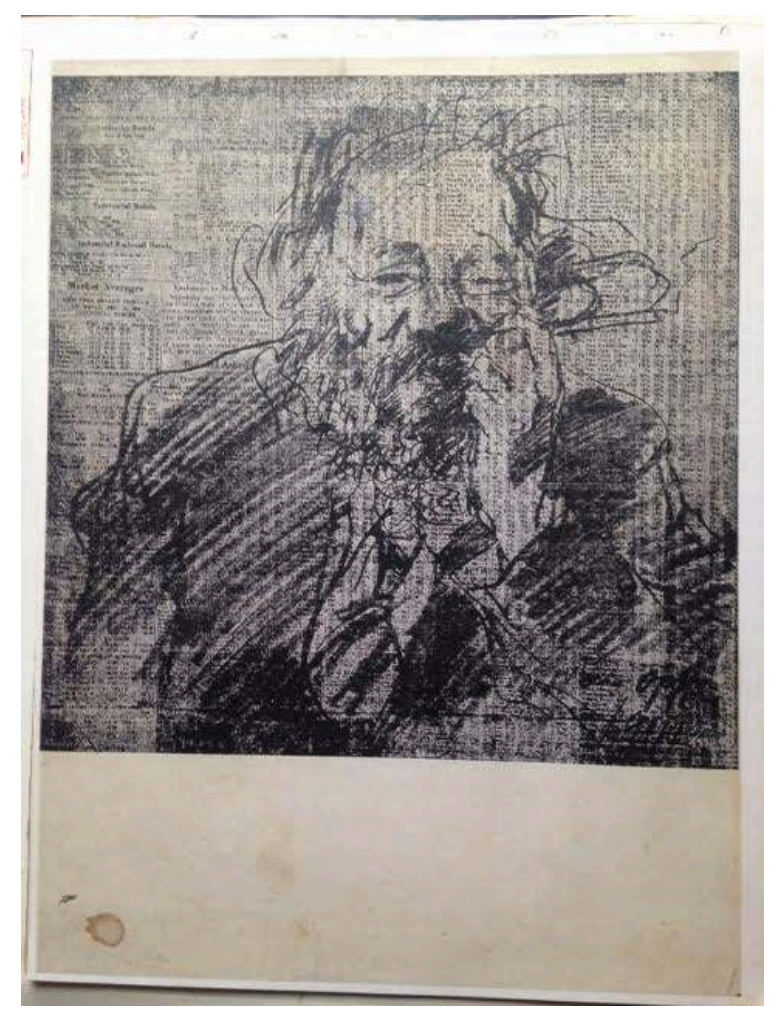

Joe Gould, c. 1944 (by Ivan Opffer)

The two anecdotes recounted in this Miranda issue are childhood memories of photographer Rachel Brown who currently lives in Cape Cod (www.rachelbrownphoto.com).

little joe gould has lost his teeth and doesn't know where to find them (and found a secondhand set which click) little gould used to amputate his appetite with bad brittle candy but just (nude eel) now little joe lives on air 
Excerpt from a poem about Gould by EE Cummings

1 Well, Joe Gould may have lost them in Truro, Mass. during the summer of 1943 when he unexpectedly turned up to visit my parents. His bus ticket had been provided by Gould's literary and artistic acquaintances in Greenwich Village who had probably wearied of his panhandling, his drunken binges, and his summer odor. He had only one suit, much too large, and he seldom, if ever, bathed. Still, he was tolerated, enjoyed even, for his humor and encyclopedic mind, and known for his obscure and mostly unpublished manuscript, An Oral History of the Contemporary World, in which every conversation he heard or overheard was recorded in hundreds of notebooks.

2 Anyway, his well-meaning friends wired my parents that Joe was on his way. He would occupy my bedroom and I would be moved to the attic.

3 The bus stopped in front of the only shop in Truro center, located across the road from what is now the Blacksmith restaurant and Truro's Cobb Library. My father met him as he stepped off the bus. Faces dropped, as Joe looked like the disheveled, dirty, homeless person that he was. One wonders with sympathy about his fellow passengers on the bus. And, to the dismay of my parents, aforementioned "friends" provided a one-way ticket only.

4 Until that moment, I, as a normal 7-year-old, had been enjoying idyllic summer days on the Pamet along Castle Road, swimming at high tide at the Sladeville landing, picking wild berries and beach plums, trying to grow a little garden in the sand, cycling around on a small blue bike given to me by a neighbor. Sometimes I would cycle all the way to the other side of the Pamet to the Depot Road railroad bridge where I could swim with friends, jumping off the trestle when the water was high.

5 We had no car or telephone. Ice was delivered weekly in blocks for the ice box. Milk came by a milk truck. Groceries from Burch's Market (now Angel Foods) in Provincetown also delivered. These were war years but to a seven-year-old, life seemed really great, even though money was short.

6 My father, a published but impoverished writer, bailed fish at John Worthington's fish plant in Pond Village, North Truro, and sometimes brought home fresh fish, often mackerel. If there were plenty, I could sometimes sell the extras to the sladeville summer people for twenty-five cents apiece.

7 My mother, who had been a member of Martha Graham's first performing troupe, typed manuscripts for several writers around. As she had a master's degree in early education she also served as principal of Truro Central School the year the permanent principal, Joe Peters, was called into military service.

8 Now, here comes Joe Gould. Joe was well known to the artistic and literary circles who frequented the Minetta Tavern and other Village bars. He has been written about by memoirists and literary historians such as Joseph Mitchell and Jill Lepore, not just as a notable Greenwich Village character, but also as the author of the obscure and somewhat mythical unpublished manuscript, An Oral History of the Contemporary World ${ }^{1}$. This manuscript contained every conversation he heard or overheard and was recorded in hundreds of notebooks that were stored all over New York City.

9 My everlasting single memory of Joe Gould was the sight of him descending the stairs one morning, stark naked. It wasn't until I saw the Cummings poem years later, cited 
above, in which Gould is described as a" nude eel" that I fully understood why we need poets.

10 I don't know how Joe's departure ever came about, but eventually my bedroom was scrubbed up and life became what may laughingly be called normal. ${ }^{2}$

\section{NOTES}

1. My father, Slater Brown, and Malcolm Cowley published only one segment of it, 64 pages in Broom, October, 1923. Their experiences are recorded in Cummings' memoir The Enormous Room which will celebrate its centenary year in 2022 with a new edition edited by Nicholas Delbanco. See also "Social Position" by Joseph Gould, in Broom: An International Magazine of the Arts, Volume 5, Number 3, October 1923: https://bluemountain.princeton.edu/bluemtn/cgi-bin/bluemtn? a=d\&d=bmtnaap192310-01.2.11\&e=-------en-20--1--txt-IN-----

2. Published February 20, 2020 in Provincetown Independent.

\section{INDEX}

Mots-clés: Provincetown, Truro

Subjects: American art

Keywords: Provincetown, Truro

\section{AUTHORS}

\section{RACHEL BROWN}

Photographer

website: www.rachelbrownphoto.com

brown.dejean@gmail.com 